\title{
6. Hip Hop in Manokwari: Pleasures, Contestations and the Changing Face of Papuanness
}

\author{
Sarah Richards
}

Hamburgers and evangelical Christianity are highly successful American exports and so too hip hop has proven to be 'the cultural form most widely appropriated into new contexts around the world' (Bucholtz 2002: 543). In Manokwari, the capital city of the province of West Papua, young people have passionately embraced the music and music videos of American hip hop at a time when cable television and online networks have displaced national control and censorship over print and visual media. Locally referred to as 'lagu rap' (rap songs), ' $r$ ' $n$ ' $b$ ' (R and B) or 'lagu karpet dans' (carpet dance songs), commercial hits manufactured by the hip hop industry are popular amongst men and women in their teens and twenties. Since it became a capital in $2003,{ }^{1}$ new digital platforms, more reliable electricity and increased access to money in Manokwari have facilitated the consumption of American hip hop. The music is watched on MTV and the internet, and downloaded onto laptops, android-platform cell phones and other music file-holding devices. This African-American cultural form, characterised by four elements (rap music, DJ-ing, break dancing and graffiti art), emerged in the 1970s as a resistant expression to white American hegemony and urban hardships (Chang 2006). In the last two decades hip hop has become a globalised genre appropriated and recontextualised within diverse cultural settings at the same time as becoming a corporate complex that inscribes image and lifestyle through commodities, verbal and body language, and attitude (Kitwani 2004). Hip hop as a marker of lifestyle and identity is apparent amongst Papuan youth who dress in the iconic styles of this genre, wear t-shirts with images of their favourite artists, perform breakdance in the streets and sketch graffiti art on urban walls.

The aims of this chapter are twofold. One, I examine the engagement of Papuan youth with American hip hop as well as the opinions of parents about these engagements. Two, I ask what interests in and opinions of hip hop can tell us about the changing shape of beliefs that Papuans are a good and worthy collective, what I call the Papuan pride movement. Taking as my starting point the notion that meaning is not passively received but created through negotiations between cultural context, media content and the priorities of audiences, I explore local

1 In January 2003, a presidential decree (Inpres 1/2003) was issued to divide the province of Papua into three. To date only two have transpired: Papua to the east and the western division now called West Papua (Papua Barat). 
reception to American hip hop in Papua as a way of inquiring into political and moral concerns in Manokwari today. As we shall see, Papuans read hip hop in either a positive or negative light depending on their relationship to complex historical intersections constituted by racist histories, political and social change and emergent religious tensions and moral anxieties in their city. For younger enthusiasts, hip hop presents as a global black aesthetic (Stemmer 2013; Ellis 1989) which, in the context of racial histories and landscapes, is being appropriated to configure an esteemed vision of Papuans as attractive, stylish, talented and potentially wealthy. The decreasing and more outspoken cohort who oppose hip hop do so on the grounds that it is 'un-Papuan', undermining of a Christian-traditional way of life and also threatening of school success and even economic prosperity for Papua.

That hip hop incites both claims to Papuanness and provides aesthetic resources for uplifting ethnic esteem amongst young Papuans suggests that Papuan identity and nationalism is moral and emotional as well as symbolic and political. To date these dimensions have been unexplored in contrast to understandings of Papuan national identities based on a shared phenotype (black skin, frizzy hair), religion (Christianity) and histories of suffering (Farhadian 2005; Chauvel 2005). Papuanness is a sentiment of pan-tribal identification that is generated through histories of perceived cultural and racial oppression and relies on stereotypes to position Papuans as a collective that is distinct from Islamic Indonesians. In recent years, Papuanness has become articulated via new digital technologies and social media and is configured through idioms of Christianity, tradition and love of land (which informs the popular expression, Tanah Papua, or Land of Papua). In the literature Papuanness is associated with politics, an identity that is intimately entwined with nationalist aspirations for merdeka, a word that translates as freedom but has semantic associations beyond national secession (Kirksey 2012). Scholars tended to have located the nexus of Papuan/merdeka in overt symbols of independence, religious scripture (Farhadian 2005; Rutherford 2003) and traditional expressions, especially song (Rutherford 2003; Glazebrook 2004; Smythe 2013).

This paper expands the frontiers of our understanding of Papuanness by exploring its lesser known and emergent properties: how it is also a realm of moral proscription (behaviours and expectations attached to being Papuan) and a zestful energy of ethnic pride that may or may not be attached to political aims of merdeka. Understanding Papuanness in the latter sense, as a collective energy that animates pride, allows us to identify how, at the heart of contested meanings, lies a pathos of missed meaning between those who are pro and those who are anti-hip hop. Whether mediating the hip hop imaginary in ways that promote Papuan beauty, talent and goodness or opposing this imaginary by recourse to an 'authentic' culture and Christian morality, parents and youth share a common impulse - to invigorate a pan-Papuan identity with virtue, dignity and pride. 
This paper is based on 27 months of fieldwork with 'coastal people' (orang pantai) in Manokwari between 2003-2005 and 2011. This diachronic perspective provided a vantage to view practices and attitudes to hip hop and the broader cultural field as dynamic and evolving. 'Coastal people' is an emically derived term to designate Papuans who originate from islands in and around nearby Cenderawasih Bay or mainland regions who consider themselves different to both mountain Papuans and western Indonesian migrants. My informants were mostly born and raised in Manokwari with the vast majority identifying as from Biak and Numfor islands ${ }^{2}$ and were neither the richest nor poorest members of society. They spoke Indonesian as their first language, valued education and employment with the civil service, and most were government employed or supported by someone who was. They were committed to a variety of churches but mostly Protestant denominations. ${ }^{3}$ Though Papua and West Papua provinces have pluralistic religious and ethnic landscapes, my informants are part of the indigenous majority who are of Christian faith and hold their Papuan Christian status as a marker of opposition to the 88 per cent national Islamic majority (Perwita 2007: 1; Farhadian 2005). In the following I provide some cultural and political context for reading hip hop in Manokwari and describe current understandings of pan-Papuan identity and cultural pride. I then present some meanings of hip hop for older and younger Papuans respectively, followed by a discussion of these meanings, their point of convergence and their relevance for understanding configurations of Papuanness in Manokwari.

\section{Hip hop culture: Local uptake of a global form}

As I watch television with a group of teenagers one afternoon, Bacchanalian scenes of MTV Asia flicker across the screen. It is hip hop hour and as hypnotic beats fill the room our gaze is turned on toned black and golden skin. In the first clip, young women dance in red sequined bras and matching shorts that reveal their leg line. The young men in the clip, paired with the girls, have hairless and glistening chests, they wear sunglasses, tight low-cut denim shorts and puffy, expensive sneakers. I miss the name of this artist but take note that the next clip is by Jay $\mathrm{Z}$ and Kanye West, who maintain a cool masculinity while modifying a car and racing it. In the next clip, Rihanna sings in mesmerised union with a man. Sexual longing is fetishised with camera shots of her long,

2 Biak-Numfor are adjoining islands in the Cenderawasih Bay with large and historically migratory communities.

3 Most informants identified as orang GKI (Gereja Kristen Indonesia; Christian Church of Indonesia), the biggest church in town, but many were also orang GPdI (Gereja Pentekosta di Indonesia; Pentecostal Church); GBI (Gereja Bethel Indonesia; Bethany Success Family); GPKAI (Gereja Persekutuan Kristen Alkitab Indonesia; Christian Bible Church of Indonesia); Gereja Katholik (Catholic Church); GSJA (Gereja Sidang Jemaat Allah; Assemblies of God); and GKII (Gereja Kemah Injil Indonesia; KINGMI). 
orange-nailed hands entwined with his fingers, their faces often poised to kiss, her long legs ending in stilettos and entwined around him. This clip, racy by public Papuan standards, is tame relative to the next, by Nicki Minaj. With a doll-like face plastered in makeup and pulling contorted expressions, the singer moves her body in hyper-sexualised moves. At the beginning, she dances with half a dozen lookalikes in denim shorts and singlet tops revealing their bra and midriff. At the end of the clip the lookalikes are in white leotards, glowing under ultraviolet light, performing writhing lap dances on buff men sitting on chairs. The audience is expressionless as all eyes are fixed on the show. When my friend's mother arrives home with her younger sibling, the channel is switched to a less confronting Javanese soap (sinetron).

American hip hop is one of multiple 'mediascapes' (Appadurai 1990) constitutive of new social imaginaries in Papua. In the mid-2000s Papuans listened to it through pirated CDs sold cheap at the market, which were often copied and shared between peers. Mobile phones are now the prime technology where hip hop is downloaded, stored shared and, for the growing number with android platforms, watched as video files. Hip hop is a genre that jostles with others emitted from CD shops, karaoke bars and public buses including lagu India (screen hits from Bollywood), songs associated with specific regions (i.e., lagu Jawa, lagu Ambon, lagu Manado) and other kinds of lagu barat ('western song') that include singers such as Mariah Carey and Englebert Humperdinck.

In general, Papuans in Manokwari classify music into three spheres: lagu gereja (church music), lagu daerah (traditional songs from a particular region) and lagu dunia (world/secular music). Within this scheme, hip hop falls within the latter category. In contrast to traditional and church songs that are considered 'good' because they connect Papuans to their history and to God, lagu dunia is described as a fickle pleasure at best, morally eroding at worst.

During my first fieldwork period hip hop was referred to as musik karpet dans (carpet dance music) after the squares of mat that boys, and less often girls, used to cushion dancing bodies. Building on older embodiments where youth used their bodies as a tool of expressive play, the vigorous gymnastics of hip hop dance found a ready audience in Papua. Public dancing took two forms. There were groups of dancers who put their carpet mats and a boom box on the ground close to shops in the evening and danced often until about $9 \mathrm{pm}$ or until the adat (customary, traditional) police or an irate trader moved them on. A more formal platform manifested as competition dance, where same-sex groups of up to a dozen dancers competed in a government-built hall. Whenever I was a member of the audience at these events, one of a hundred or so who sit in a stiff chair in a hot and stuffy hall, I was always amazed by the athleticism and panache of the dancers. Dance groups went to great effort designing and sewing 'uniforms', using shiny and bold-coloured materials worked into body-covering 
trousers and shirts. Faces and synthetic clothes quickly became wet during the performance as troupes engaged in high-energy, tightly choreographed dances that appeared as if straight from a music video clip, save for a significant exception. Just as their costumes were more sport than sex, so too their dancing lacked the grinding, twerking and other sexually provocative moves characteristic of American hip hop (Munoz-Laboy et al. 2007).

\section{From dance to style: Development and moral anxieties in the Gospel City}

The commercialisation of hip hop (see Chang 2006) has dovetailed with the radical growth of Manokwari and concomitant fears about the moral impact of social change on the town's youth. In 2005, all young women save for those said to be nakal (naughty, sexually immoral), sombong (arrogant) or yang tidak tahu $m_{a l u}^{4}$ (do not know shame) wore loose-fitting and well-concealing jeans (or skirts well below the knee) and t-shirts (or button-up shirts). Makeup was for church, jewellery was limited to little more than a necklace with a small crucifix and hair was short or tied and slicked back to look neat and straight. Fast forward to 2011. Most young women still dress like this, in what people call 'Papuan style' (gaya Papua) but there are many who no longer conform to this dress code. Especially in the late afternoons, evenings and Saturday night, times when youth like to dress up and jalan jalan (travel about without clear purpose), it is increasingly common to see girls wearing makeup, skinny jeans, short skirts and singlet tops that reveal shoulders. Though not limited to hip hop style, mimesis of hip hop celebrities is apparent in the popularity of 'bling' (bold metal jewellery), flamboyant hair styles and, for young men, baggy trousers that reveal the top of their undershorts as well as heavy chain jewellery, sunglasses, sneakers and baseball caps worn backwards.

The greater appearance of fashions that girls would, only a few years earlier, have been too afraid to wear lest they be gossiped about is related to the rapid growth and development of the town since it became a capital city of a new province. Facebook friends had warned me prior to my return five years after my first period of fieldwork that 'Manokwari has changed a lot' (Manokwari merubah sekali). These warnings could not prepare me for the scale of change I witnessed. The town had become bigger, louder and, to my senses, uglier and smellier. Tentacle-like, it wound further around Dorey and Wosi Bays, it crept into the green rainforestcovered hills beyond, there were now a great deal more shops, and grand new

4 Malu is a Malay/Indonesian word that pertains to both a state of feeling shame or shyness and ideal feminine embodiment. It is commonly described by Papuans (Munro 2009, this volume) in reference to specific affective configurations to do with loss of prestige as much as an internalised sense of shame. In Papuan contexts, malu is a category and experience shaped by local structures, cultures and biographies but, in contrast to other parts of Indonesia, within Papua, shame is more closely related to social standing. 
government offices lined new roads. Manokwari had a number of firsts, including a gated community; a two-storey mall; a five-star hotel; and a children's birthday party venue. In 2005, the town had one traffic light that was turned off at ten o'clock to save electricity. Now there were six that operated day and night.

If the growth of hip hop in Manokwari is linked to an expanding social and urban scale, attitudes to this genre are related to complex interpretations and experiences of development. People spoke of change in epochal terms, as Manokwari having 'already developed' (sudah dibangun). They attributed this to funds sent from Jakarta to build the infrastructure and the personnel required for expanded governance. They also understood development as the result of enterprising in-migrants and the political processes of otonomi khusus (special autonomy) and pemekaran (administrative subdivisions). ${ }^{5}$ Papuan civil servants, believed to be operating within a KKN (Kolusi, Korupsi, Nepotisme-Collusion, Corruption and Nepotism) economy, were said to have become wealthier in recent years. The rising standard of living amongst some contrasted with the majority who, and perhaps with greater bitterness given their hopes for change, continue to struggle to find money in the day to day. While a growing divide between Papuan have and have nots is a new trend, the competitive advantage of migrants in a racially structured economy is a continuation of economic patterns in Papua (Upton 2009). Patterns of migration are indeed diverse and include newcomers from within as well as outside Papua, but when accounting for demographic and economic change, migrant-owned shops and houses that have sprung up, squeezed between older buildings, figure strongly in Papuan explanatory frames. In the post-Suharto landscape, Papuan disgruntlements with economic exclusion are increasingly vocalised and amongst the more conservative, increasingly through the axis of religion. The changing ratio of church spires to minarets has provoked concern that the Gospel City (Kota Injil), as Manokwari is famously known due to being the site of the first mission in Papua ${ }^{6}{ }^{6}$ is becoming Islamicised and losing its Christian character.

Within this broad context of economic and political concern, hip hop is implicated in discourses of 'sex panic' (Herdt 2009), an analytic offshoot of moral panics theory (Cohen 1980). Though hip hop music, fashion and dance are not a strong target of public concern, it is fuelling a generalised anxiety that youth cultures are sexualising as they are changing. Youth interest in edgy and sexy appearances are, for the morally concerned and as is common in scenarios of moral panic (Cohen 1980), a sign of poor foreign influence and a 'slippery

5 The Special Autonomy (Otonomi Khusus, Otsus) Bill was approved for Papua in 2001. It was intended to address Papuan grievances to centralised governance by granting greater power over local administrations and budgets. In practice it has been a contentious and fraught legislation that has benefitted few. Pemekaran, the process of proliferating administrative divisions in the scramble for power and resources, has been an unanticipated consequence of the Otsus bill.

6 German Lutherans from the Utrecht Mission set up camp on nearby Mansinam Island in 1854. 
slope' to social decay and ruin. Even though new fashions are modelled on an American cultural form, local histories and nationalist concerns configure 'the foreign' as 'Indonesian' in discourses of panic. To be clear, pre-marital sex is not the only target of panic, ${ }^{7}$ yet the flush of cash through bureaucratic veins combined with the felt need or desire for money and commodities are triggering fear that more young women are exchanging sexual services for money (especially to buy mobile phone credit) or gifts of jewellery, clothes and mobile phones. Within the frame of Christian sensibilities, daily gossip, speeches of adat leaders, sermons and media editorials are preoccupied with the behaviour of youth who are said to be having more sex, with the possibility of more children being born out of wedlock, and with schoolgirls said to seduce married men and so 'destroy families'. From an anthropological perspective, seismic shifts in pop culture, fashion and sexual culture are the result of complex intersections at local, national and global levels and cannot be reduced to the influence of "pop culture' or even 'hip hop'. Yet the salience of hip hop music and dance in the lives of many young people gives substance to parental concerns that youth are acting un-Papuan by following a foreign and sexually dubious cultural form.

\section{Papuanness: The wider context}

Papuanness is a 'revitalisation movement' in Wallace's (1956: 256) classic sense of 'a deliberate, organized, conscious effort by members of a society to construct a more satisfying culture'. Revitalisation is a promising analytic because it can account for Papuan identity as political-symbolic but also provides analytic space to capture the moral and emotional dimensions of behaving and feeling Papuan. Before I ask questions and comment on these dimensions, I provide a brief history of Papuanness. The term 'Papuan' to designate an overarching ethnic identity that runs in parallel to localised identifications is not new, and is found in the colonial (Chauvel 2005) and even the pre-colonial era (Rizzo 2004). As a dynamic axis of identity, Papuanness has evolved in recent years from being unspeakable, a term associated with 'anti-government, anti-Indonesian and anti-military' (Farhadian 2005: 156) to being the subject of a discursive explosion.

Vocal expressions of symbols and imaginings of Papuans as a unified ras (race) were made possible by cracks in state machinery and political reforms at national and provincial levels following the fall of Suharto in May $1998 .{ }^{8}$ In the

\footnotetext{
7 Pre-marital sex is not the only target of moral panic for Manokwarians are also excessively concerned with orang mabuk (drunk men), opportunistic theft and greed-induced corruption.

8 Scholarship by Farhadian (2005) highlights the role of Christianity in fortifying the sense of Papuanness by pointing to the power of faith and religion in political opposition. The renewed interest in being 'Papuan', he argues, can be traced to GKI and Catholic reports published in Indonesian in the mid-1990s that detailed human rights abuses across the province (Farhadian 2005: 155).
} 
new climate of reformasi (reform) characterised by new freedoms of speech and government accountability, 'civilian political expression in Papua flourished' (Ballard 2002: 468). Democratic reforms were limited, and many Morning Star (Papuan Independence) flag raisings ended with military fire in the second year after Suharto's resignation, but a Pandora's Box of disgruntlement and desire had been opened and Papuans were less fearful. An iconic moment in this respect was the Great Consultation (Musyawarah Besar, MUBES) of 2000 when Papuan leaders from across the province arrived in Jayapura to enter a dialogue forum on the future of Papua dressed in striking traditional finery (ICG 2001; Chauvel 2005; Ballard 2002). The symbolism of this gesture, in light of New Order histories that have denigrated Papuan culture, spoke volumes about a willingness to push Papuan heritage and identity onto centre stage.

Expressions of Papuan pride, though by different actors and with different effects, have circulated through a variety of realms in the service of the 'greater good', however defined. For instance, the importance of pan-Papuan sympathy for the goal of merdeka (freedom) is the subtext of the Morning Star flag and the Star of David, which have both become more ubiquitous in visual culture (Farhadian 2005; Myrttinen this volume). Papuanness is a concept mobilised by HIV prevention campaigns, it is manipulated by politicians to secure votes in the new system of direct elections, and it is a key underpinning of new adat organisations such as Lembaga Masyarakat Adat (Traditional Community Institution, LMA) and the Dewan Adat (Traditional Council). Visions of Papuanness are found in new local media, in songs that praise Papuan land and customs, and in an emergent genre of books that define 'the Papua problem' and recommend spiritual, behavioural and educational solutions to help lift Papua from relative economic disadvantage (Giay 2001; Flassy 1999; Poli et al. 2008). These diverse examples attest to the emergence of Papuanness as a highly elaborated cultural trope in contemporary Papua.

Papuanness resembles other discourses of sub-national difference found throughout post-Suharto Indonesia that draw on adat and religion to construct unique identities (Purdey 2004; Davidson and Henley 2007). Notwithstanding regional parallels, the content and intensity of contemporary Papuanness is shaped through histories of largely reluctant engagement with nation. Relationships to Indonesian governance, as this volume highlights, are highly diverse and characterised by deep entanglements (Kirksey 2012). A study of Papuanness, however, requires that we read history through the lens of negative experiences and opposition to institutions and agents of the state. It would take me too far afield to document how New Order dynamics have dialectically charged a passion for Papuanness but, as it is critical to understanding the resistant potential of hip hop, some words on histories of cultural and racial denigration are necessary. Building on colonial categories of civilisation/ 
primitive, state interventions to meet the aims of economic progress and national stability were justified by discourses of Papuans as a backwards, savage and undeveloped people (Kirksey 2012). This racialised gaze has taken many forms such as Java-centric programs and policies ${ }^{9}$ and repressive controls over cultural expression. ${ }^{10}$ It has stripped Papuans of rights in the case of land and resource alienation at the hands of non-Papuan migrants and foreign-owned companies and dehumanised them to a violent military apparatus (Hernawan this volume; Chauvel 2005; Kirksey 2012; Braithwaite et al. 2010). This is not the whole story, and for every Papuan I knew who had felt discriminated against by migrant teachers, employers or neighbours, there was another who had migrant friends from school, work or church. Within spaces of intimacy, there is both the potential for racism to be acutely experienced and potentially subverted through relations of dissidence. ${ }^{11}$

Such histories have become etched into consciousness through what Munro (2013, this volume) calls, after Robbins (2005), 'discourses of diminishment'. The idea that racial constructions can produce 'humiliation and a sense of inferiority' (Munro 2013: 27) can be traced to the theories of Marshall Sahlins (1992) and before him, Franz Fanon's (1986) evocative idea of the colonial mirror and need to decolonise the mind. In the context of Papua, emergent discourses of Papuanness can be understood as fulfilling the psychological need to assert a collective sense of dignity by reinscribing the mindset imposed on them through the racial national imaginary. In sum, Papuanness is an evolving and dynamic construct of grassroots communities, Papuan intellectuals, politicians and community leaders, and scholars have provided valuable insight into the macro-determinants of political identity and vision. Important questions remain regarding other facets of meaning, meanings that may or may not be tethered to realpolitik. By investigating attitudes to hip hop, I ask how does Papuanness manifest morally and emotionally to raise the esteem and dignity of a people?

\footnotetext{
9 Even trans- and spontaneous migration has been justified by, as one of many reasons, the modelling of Javanese morality, culture and industry.

10 The New Order state held a tight rein on adat (culture, custom, local history), only permitting its expression in the service of economic growth and nation building. Building on Dutch efforts to classify the customs of the 'East Indies', the New Order domesticated culture by officialising regional songs, dances and dress (Hellman 2003). Transforming culture into 'spectacle' (Acciaioli 1985) boosted the tourist economy and visually represented the national motto 'Unity in Diversity' in times of parade and other events of national celebration. In regions with desires for secession, objectifying culture had the additional benefit of keeping track of customary expressions that may be veiled political statements. Surreptitious enactments of 'culture' could be interpreted as a sign of potential treason and so be punished by the armed forces.

11 Due to its historical proximity to eastern Indonesia, it would be possible to write a history of love between Papuans and migrants in the Bird's Head region.
} 
From 'Stone-Age' to 'Real-Time'

\section{Hip hop: Un-Papuan versus inevitable}

The athletic style of restrained hip hop dance in Papua suggests that as it has gained traction, hip hop has been reconfigured through Papuan codes of sexual and gendered ethics. This is not how many parents understand the situation and since its appearance on the social landscape, hip hop has been perceived as morally suspect. During my first period of fieldwork I found little nuance in opinions. All parents, many heartfelt while others seemingly in a knee-jerk reaction, expressed the belief that karpet dans was a negative influence. Reasons for this were intuitively straightforward - the music was 'tidak baik' (no good) because it was 'bukan asli Papua' (not authentically Papuan). In this statement we can see that as a decidedly 'foreign' cultural form, hip hop is more than incommensurate with the 'local', it is corrosive of Papuan moral character. Narratives of culture as something that can be lost to modern ways have been documented elsewhere in the Pacific and, as in these cases, what comes to be considered 'local' and 'foreign' are not geographically anchored but morally negotiated outcomes (Knauft 2002).

By the early 2010s, attitudes to hip hop were as diverse as attitudes to development, which hinged on personal politics and biographies and could be plural, ambivalent and contradictory. The formulaic interpretation of hip hop as bad and un-Papuan was still in circulation, yet this opinion had shifted to a conservative fringe; parents that were described by others as 'strict' (berdisiplin) or, in ways suggestive of their ethical decision-making framework, as 'adat people' (orang adat) or 'fanatical Christian' (Kristen fanatik). This latter term was new, no doubt borrowed from global religious landscapes, and spoke to a growth in (or at least classification of) what Cohen (1980: 1) has referred to as 'right thinking people'. At the same time, increasing numbers of parents have come to condone, accept and even enjoy the hip hop music and dance of the young. They represent a growing middle class that may be dissatisfied with aspects of social change but, overall, accept development. 'This is how it is now in Papua', one friend told me when I asked why so many parents had changed their minds about hip hop. As if an afterthought she added, 'Manokwari has already developed.'

Ani, an unusually outspoken and mature 13-year-old, told me while her parents nodded in agreement: 'Kids are the same everywhere ... they all like this music'. This idea, that hip hop was inevitable because urban growth and technological change had catapulted Papuan youth into the time-space dimensions of peers in large global cities was common. A 57-year-old Serui-Biak fisherman, who was melancholic about the growing size of the city, looked to the horizon as he explained the new dance craze: 'We have entered zaman globalisi (era of globalisation). Our kids are like kids in other big cities, they want to listen to modern music and follow selebriti (celebrity).' Others, such as grey-haired mama 
Aroy, a Biak woman with 28 grandchildren, were positively enthusiastic: 'I love to watch the children,' she grinned with betel-stained teeth, 'They are very clever at dancing.'

The polarisation of opinion can be understood in relation to a broad fracturing of Papuan society into those considered highly moralistic and the majority who, at my prompting, described themselves as a 'orang biasa' (usual people, normal people). As a heuristic, we can visualise this as a spectrum where all Papuan parents value Christianity, tradition and disciplined childrearing to varying degrees but some enact these moral templates with greater vigour. A 52-yearold neighbour, a civil servant and lay pastor with the Pentecostal Church, held opinions typical of conservative views: 'This kind of dance is not good for Papuan children. When they follow this style, they follow foreign ways and forget adat Papua (Papuan customs).' As a Pentecost, readers versed in Melanesian literature might find my neighbour's coupling of morality and culture surprising. Given that fundamentalist denominations are well known for demanding followers sever from old ways of life to bring about a new kind of spiritual individual (Robbins 2004), his seamless reference to tradition alludes to how, in Manokwari at least, these twin spheres may be fused in the service of a moral identity.

To be sure, there are people known as 'adat people' (orang adat) and as 'church people' (orang gereja); adat is selected and modified through Christian frames but not vice-versa. Frictions are not entirely absent between the two spheres. Yet from the GKI Reverend who incited Papua's future when urging youth to follow Christian ways of life in a Gospel City Day speech, to the pastor who requested I look in my anthropology book to re-learn how to build traditional houses, to the traditional costumes the majority wear in an increasingly popular annual parade that celebrates the arrival of the Gospel, to the priest who danced wildly at a bridewealth party, Christianity and tradition are largely entwined constructs that are drawn upon in discourses of what makes Papuans unique and special. For more conservative Papuans, they are also schema for drawing clear bounds between good and bad behaviours.

To understand claims that equate hip hop with Papuan inauthenticity, we need to ask what an authentic Papuanness might be? Such a question highlights that Papuanness is more than a matter of culture (budaya), land (tanah), customs (adat) and history (sejarah) that are distinct from other regions and peoples in Indonesia. Papuanness implies a special character too. The notion that 'Dani', 'Asmat', 'Biakis' and 'highlanders' (orang gunung), for example, have certain attributes is common knowledge amongst Papuans though what these attributes are differ depending on if one is or is not a member of the group. So too is Papuanness, precisely because of its grassroots legitimacy as symbol of unity, becoming a discourse of being Papuan, of possessing a moral character that is based on respect for religion and tradition. 
In the context of social change and moral anxieties, being Papuan means to have a different moral character to Indonesians, a character people were keen to share. For instance, Papuans were said to be emotionally expressive and open. 'We are not like Javanese who are always calm and smile ... then knife you in the back when you are not looking,' explained a 33-year-old Biak woman, 'If we Papuans are angry, you will know. Our character is honest (sifatnya jujur).' Papuans, due to both customary living and Christian ethics, are thought to be inherently caring, willing to share the abundance with which God has blessed them. ${ }^{12}$ 'Papuans don't merantau (leave Papua in search of economic opportunities),' a 22-year-old Biak man told me, 'because we have plenty. God gave Papuans oceans full of fish and good soil to grow vegetables.' A common expression that many recited was 'Papuans cannot be poor because they are rich in family'. An old, angular man spoke to me one rainy night, saying: 'We are a Christian people but it is also our tradition to care for other people. In Java people can die of hunger and no one knows. They find the body months later. That would never happen in Papua. No one goes hungry because we share, and God has blessed Papua with fertile soils and many fish.'

Given greater entanglements with national and global cultural flows, there is a certain irony in drawing rigid boundaries to create ethnic essentialisms. Giay and Ballard (2003) point to problems in creating a Papuan identity based on allegedly pure forms. Such constructions may be read as a response to contemporary entanglements, a desire to locate laudable moral qualities in order to simplify a complex situation and bestow dignity upon the collective. That my informants say that Papuans have a certain character does not, it is worth mentioning, preclude other kinds of social identifications nor is it to deny that Papuan cultures and identities are a mediated product of geographic and technological border-crossings. ${ }^{13}$ I concur that Papuanness is accomplished through perceptions and interactions with 'audiences' (Rutherford 2012); that Papuans express affiliation with a tribe, a village and the ethno-nation; that they often identify with other Melanesians and share community with globalised Christian fellowships. The point is, as anthropologists have found in other world areas where indigeneity is a space of purity and goodness (Brison 2008; Gagné and Salaun 2012), Papuanness presents as a sacred certainty that Papuans are special people with rich customs and distinct virtues.

12 What Wardlow (2006: 35) calls 'auto-orientalism' is a common phenomenon whereby barbs and shadows are contained within dominant constructions. I have heard Papuans, in a candid moment, blame their lack of progress on a general laziness and tendency to gossip, which are seen as a dark side of their otherwise good sociality.

13 Intersectional spaces, for instance, include transnational fellowships (Farhadian 2005); relationships with international activists (Kirksey this volume); the (impossible) domestication of foreign goods and technologies (Rutherford 2003); colonial representations of Papua (Cookson 2008). 


\section{Hip hop and worries about sexual moral decline}

Sexual morality is an example of a cultural realm where the contours of Papuanness are becoming fixed as a set of standards used by some to judge the actions of others. Premarital chastity is considered a quintessential Papuan value upheld by interpretations of the custom of bridewealth and Christian imperatives. Sex before marriage is said to be a 'sin' (dosa) and can be avoided through obedience and respect for parents, daily discipline and a personal relationship to God though prayer and a demure comportment and modest dress, the kind noted earlier as a 'Papuan style'. In these moral interstices, hip hop is perceived as an indiscriminate element in a cluster of developments feared to be weakening Papuans' moral fibre. Tom, a Serui man and a senior official in the Department of Education, spoke of hip hop indirectly when expressing concerns with a decline in the sexual morality of youth:

This music the children dance to, it is not polite. You see them at the market on Saturday night, the music loud, boys and girls mingling, girls in rude clothes like tali satu (one string, singlet tops). This is not Papuan behaviour. It is bad for Papua's future. These kids listen to music, they dance, they drink, are delirious and have sexual relations. Girls get pregnant, leave school, there are so many children now who do not know their father.

Hip hop, for the conservative, indexed moral decline in an increasingly cosmopolitan city, the changing nature of which had facilitated mobility, anonymity and relaxed moral surveillance. It was associated with a set of immoral practices, revealing clothes, hetero-social mingling and drinking alcohol, that were clustered with illicit sex and personal and political ruin. If Tom speaks the language of moral panic by invoking the slippery slope, his specific concern with children born without fathers and Papua's future alerts us to how the 'political moment' (Weeks 2012) of Manokwari is configuring sex panics in which music and dance figure prominently. Economic disappointment is heightening fears that young women, especially with the rise of 'sugar daddy' civil servants, are more willing to sell sexual services. Growing numbers of migrants and the marginalisation of Christianity in the Gospel Town is raising the stakes of what kinds of behaviours are essential for helping Papuans travel the path to economic prosperity. This taps a meta-discourse raging in Papua about what factors are preventing the realisation of wealth that God, by virtue of bequeathing them great natural resources, had obviously meant for Papuans.

For 'regular people', hip hop was said to be a medium for expressing modern individualism. Even with the liberalisation of attitudes to foreign pop and culture, evaluations of broad shifts in the bounds of modesty in fashion could 
never be dislodged from the hegemony of a Christian sexual morality. Riasa, whose 16-year-old daughter wore the shortest skirts in the neighbourhood, looked me in the eye as she explained, 'It is just fashion. They are still good kids.' This argument was typical of parents who defended sexy looks by drawing a distinction between surface aesthetics and inner goodness. This comment highlights how the parameters of shame, as ideal feminine embodiment, are being renegotiated within a shifting social terrain. At the same time, that more flesh and flash looks are being defended belies the normative power of Christian standards of sexual goodness.

The foreign can be a source of potency and value in this Bird's Head region (Rutherford 2003) but hip hop alerts us to how the foreign is also a source of threat (see also Butt this volume). The young know hip hop as American in origin, but within reactionary discourses hip hop becomes a generic element of 'outside influences' (pengaruh dari luar) where 'outside', in the context of immediate concerns about migration, Indonesian media saturation and Islamicisation, stands for Indonesia or Java. Papuan friends were sure that the looks, aspirations and behaviours of the young had changed in recent years because they were 'following outside' (berikut di luar), which is to say they were 'following Indonesia' (berikut Indonesia). Fitting the continuum of moral orientation, some did not see this as necessarily displacing the moral compass of youth while others were sure that to adopt the behaviours of migrant peers and glitzy Javanese actors and models on television was to lose Papuan-Christian values. If we switch signifiers, from 'westernisation' to 'Indonesianisation', Papuan moral panics resemble moral panics occurring across Indonesia where Islamic and pro-family organisations are demonstrating 'moral outrage' against 'free sex lifestyles' as promoted by 'the West' (Schaefer 2013). Continuities with Islamic and other conservative groups in Indonesia notwithstanding, attitudes to popular cultural forms like hip hop are mediated through histories of social dissatisfaction with development and the nation.

\section{Other problems with hip hop}

Some parents believed hip hop to be a problem because it interfered with academic performance. Educational success is a factor widely believed to be a key to lifting Papuans from alleged ignorance and conditions of poverty (Stasch this volume; Munro 2009, 2013), yet links between hip hop and schooling prioritise the personal and practical over the abstract. Marta, a mother of two teenage daughters, explained this problem on a wooden bench under the shade of a mango tree one humid evening: 
Papuan kids are crazy for this kind of music but I don't let my daughters follow. The problem with this kind of thing is that when kids stay up late practicing and dancing they are tired the next day. They cannot catch the learning. All their concentration, all their effort has been directed into learning the dance steps. So they are drowsy and not thinking of their schoolwork.

Marta, who was an exemplar of a berdisiplin (strict) parent, believed karpet dans to be so physically strenuous that it detracted from a child's ability to concentrate on school. School is highly regarded as a means to obtain the diploma needed to apply for waged employment and so, given familial investment to pay for school fees, uniforms and schoolbooks, hip hop can threaten to derail future economic stability. Reference to hip hop as redirecting effort from school is also based on 'local biologies' (Lock 2001), understandings of bodily capacities as finite and needing to be regulated by balance in day-to-day routines. Spending the evenings dancing runs counter to ideas of health as built from moderate and consistent regimes of work, sleep, study and prayer.

The last oppositional discourse I mention complicates the generational and moral lines I have drawn in pro- versus anti-hip hop stances. There are young men who problematise the sexy and edgy looks of young men and women but without a sexual moralism. This position can be illustrated by Teus, a 25-yearold economics graduate with dreadlocks, who does not so much attack hip hop as the kinds of lifestyles it is promoting:

You see them everywhere, kids with long hair, lipstick, and tight jeans. Stylish, stylish, following selebriti. The problem with this is that they are forced from the outside to be like this. This is not original (asli) Papua, this is Jakarta style. These kids are not prepared for modernisation, they appear like they are already developed. They spend their time not learning about Papuan history, or working to progress Papua ... They just wake up, think about their appearance, do their hair, then go about (jalan jalan), stylish modern. What do they have at the end of the day? Nothing. When they go home there is no dinner, no lighting, a dirt floor. A sparkling mobile phone and no food. This is not progress, this is a lie.

I do not know if Teus had read Marx, whose writings are illegal in Indonesia, but his argument had clear echoes of the late German. Here, fashion is a kind of 'opiate of the masses' productive of a kind of 'false consciousness' since the slavish adherence of youth to new fashions and styles was anathema to economic wellbeing. While parents who describe youth as 'following outside' (ikut dari luar) deny them agency, Teus' reference to Papuan kids being 'forced from outside' situates them as victims, a space with greater potential for moral redemption. Teus' expresses his vision of how the younger generation can 
reclaim autonomy by learning the 'truth' of history and confronting the reality of their economic impoverishment. Only by acknowledging this truth, Teus maintains, can the young be motivated to the kinds of learning and behaviour required to usher in a better future.

\section{Hip hop: Meanings of Papuan youth}

Papuans primarily enjoy hip hop because of its melody and beat, which is said to inspire dance. 'Rap music makes Papuan kids spirited,' (musik rap bikin anak Papua semangat) said one friend. Hendry told me: 'If we hear these songs, our bodies start to move' (Kalau dengar lagu lagu ini, kami punya badan langsung mulai dans). Sixteen-year-old Ruis alluded to its therapeutic value: 'When we hear this music we forget our worries' (kalau dengar musik ini kami lupa pikiran). As Indonesian speakers, being receptive to the music over the lyrics arguably enhances this visceral pleasure. This is not to say, however, that immediate sensory pleasures are disconnected from cognition for it is precisely the emotional charge of hip hop that creates an avenue for political meanings.

Women especially stressed the value of hip hop in terms of the beauty of its singers. Naomi, a 16-year-old student from the Wandamen region, explained why she and other Papuan kids like hip hop:

You can see Rihanna and Beyonce are very pretty. They have black skin and frizzy hair like us. They show us how to wear makeup, stylish clothes and style their hair so we can look good too. Before, when I was young we saw some artists on the music video but we could not follow them. Kids now have entered the modern era, we like to follow them.

Naomi's words reveal how American hip hop artists have held appeal to young Papuans for many years but it is only since the rapid expansion of Manokwari that new freedoms have enabled celebrity emulation. They are worth emulating, she suggests, because of the similarity between Papuans and Afro-American phenotypes. The subversive potential of this identification can only be appreciated through recognising the role of Jakarta-based media and advertising industries in discourses of diminishment. While there are more diverse representations of Papua in national media and individuals are known to be celebrated for their prowess as athletes, singers and dancers, hierarchies of racial worth circulate through visual and print media as well as advertising. In moral hegemonies of beauty, pale-skinned and straight-haired people sit at the apex while darkness stands for that which is ugly, backwardness, inferiority and so bad (Prasetyaningsih 2007). While any reader who has seen Rihanna or Beyonce may question the extent to which they do in fact resemble a classic Melanesian 
look, from a local vantage they are more Papuan than they are Javanese and so provide scripts for Papuans to rework beauty within their physical parameters, effectively disrupting the reproduction of racial hegemonies in Papua.

Naomi's exegesis is supported by the relatively flamboyant hairstyles that some Papuans are adopting, clearly inspired by Afro-textured trends. Girls often like to dye their hair blonde or other bright colours and wear their hair out or straightened, crimped or extended. Teenage boys too, who only a few years earlier lacked elaborate grooming or body adornment, have come to dye their hair, often just a patch of colour, and as with hip hop artists, shave zigzags and other patterns into their locks. Hair, given histories of Indonesian denigration of and also forced cutting of Papuan hair (Cordell 2013), can be read as more than just an affordable site of hip hop expression. In ways that deserve greater attention, hair is becoming a key site of 'racial malleability' where Papuans are engaging the 'sensory modalities' (Roth-Gordon 2013: 298) of hip hop to transform experiences of their bodies in relation to a global blackness that presents as an alternative sphere of value. The resistant politics of hair was implicit in Sali's answer to my question of why she had taken the whole day to glue hair extensions on her friend. 'I don't know, something to do,' Sali replied, then after a pause, added with a wry smile, 'our crown is our glory.' According to her Biak heritage, a large, round, well-groomed frizz was a sign of moral and physical health and so a symbol of the strength of a community.

That men enjoy hip hop styles suggests these insights are applicable across the gendered divide. Men framed their interest in hip hop according to a different set of concerns. Perhaps because of the gendered double standards where men enjoy greater mobility and less scrutiny of reputation, hip hop was all about the dance for men. The music compelled dance and affirmed feelings of physical strength and talent for dance as well as provided a means for emotional release. For the more politically motivated, these sensations connected young men to Papuan history and culture. Twenty-one-year-old Solomon, a political activist and a member of a hip hop dance group, explained:

The first artists I heard were Snoop Dog and 50 cent. I was surprised when my friend played me this music. I had not heard this kind before. When I was small, there was only lagu pop (pop songs), lagu gereja (church songs), dangdut (a popular form of Javanese music). That's all I knew. This sound arrived. It had strong drum, like in Papua. This beat makes us drunk with dance. Like drum beat for our ancestors. It is very different to traditional music but still, when I dance to hip hop, I feel respect for my ancestors.

Solomon articulated an instant connection with hip hop, based on a sense that it was distinct from any other kind of music he had heard. The hip hop beat, even 
though electronically produced, was felt to have elemental affinities with the drumbeat of traditional forms of music. This connection allowed hip hop to be experienced as what Smythe (2013: 74) calls a 'living symbol' or 'participative practice that invites the physical engagement' of the body across space and time. That Solomon selected drum beat in his explanation was not coincidental. Once a sign of primitiveness, a sound pertaining to cannibal feasts and war victories that struck fear into missionary hearts (Ottow and Geissler 1857), the tifa (a tapered traditional drum) has become emblematic of a shared Papuanness. The Papuan drum, found in various regions, is played at ritual and public events, is a key motif in Batik Papua, and is considered an iconically Papuan ethnomusical item.

What we might call a discourse of black affluence is another instance of how youth reinvest hip hop with notions of Papuan worth. Both men and women expressed delight at the sight of 'orang hitam' (black people) displaying the trappings of wealth and luxury in hip hop music videos. Valeri, a self-assured 19-year-old, shared her position:

When Papuan kids watch the film clips, we are happy to see black artists (artis yang hitam) in Lamborghini, or covered in diamonds, very stylish (bergaya gaya) ... It feel surprising and good because this is not usual to see. When we turn the channel, only see white people and Javanese people, or Chinese people are rich. Why are black people not shown? There are rich black people. But when we see black people they are poor. They are hungry. They are sick.

Valeri's narrative highlights how enjoyment of what Watts (1997) calls the 'spectacular consumption' in 'gangsta rap', serves as a refreshing counterpoint to depictions of black people as universally poor or ill. In this respect she may be referring to the ongoing stereotypes of Papuans as undeveloped that can emerge in surprising guises in the post-Suharto landscape. In a recent Nutrisari commercial for instance, Papuans are depicted along with other colourful suku suku banggsa (ethnic groups) in traditional costumes in order to market the orange drink powder (Swarati 2012). Though tradition has been reconfigured as a national treasure, such representations perpetuate primitivising codes that position Papuans as backwards and living in the past. Valeri's opinion may also be shaped by the oft-shown news reports and images of Papua's HIV/AIDS toll, the highest in the nation, as well as other images of Papuan suffering, such as reports of Papuans as the latest victims of violent clashes around the province. She may even have world news reports in mind, such as from Africa where black bodies are often depicted as in trouble and turmoil. At the level of social imaginaries, when we take into account Papuans' economic disadvantages (Chauvel 2005), hip hop can generate a sense of ethnic worth through the utopian vision of black people as economically privileged. 


\section{Conclusions: Contested meanings, similar concerns}

Young Papuans in Manokwari attach distinctive and pluralistic affective meanings to the music and video aesthetics of American hip hop. Some derive pleasure and satisfaction from the glittering sight of attractive, stylish and wealthy Afro-American singers, while others are attracted to the rhythmic seduction of dance and its mood-lifting capacity. Beliefs in personal and Papuan talent for dance generate pride. For others still, hip hop can be an avenue for connecting youth to Papuan history and traditions by rendering salient the primacy of its drum beat. Parental understandings of hip hop are equally pluralistic, with some holding neutral or positive attitudes and others identifying it as a foreign influence that, as with other immoralities, is indexing and perpetuating social problems in urban life. In ways that suggest that Papuanness is more than an identity of opposition, it is an ethnic reification becoming an ethical template in a battle of moral control, hip hop lifestyles are said to be un-Papuan. Through the idiom of an ethnic essence, in other words, hip hop poses specific moral issues related to sexual purity, educational diligence and obedience to parents.

In light of research into youth cultures, there is nothing surprising about hip hop's tendency to polarise eager youth and morally suspicious parents. Though intergenerational conflict is not peculiar to modern life (Herdt and Leavitt 1998), since youth have become the target for consumptive practices that are defined in opposition to past generations (Bucholtz 2002) taste can become grounds for such conflict. Yet if we suspend the analytic of 'spirit' from the 'content' of Papuan pride, we can locate a common emotional energy and a common aim to raise the esteem of Papuans between those differentially positioned attitudes to hip hop. Whether using hip hop as a resource for subverting negative depictions of orang hitam (black people), raising esteem through creative movement or connecting with the past, or to draw attention to cultural elements blocking the reproduction of authentic Papuan selves, both hip hop enthusiasts and its detractors aim to elevate Papuans as a worthy and good people. Though one discourse is sensory and indirect and the other uses the proscriptive voice of tradition and Christian ethics, both those who express enthusiasm and opposition relate to hip hop through concerns with pride in Papua.

The pride in being Papuan through the joy of hip hop points to a significant dimension of an evolving ethno-nationalism. That is, while the political cannot be separated from the psychological, Papuanness has an affective core that exists above and beyond political discourse. In recent years, a palpable spirit, for want of a better word, is breathing life into feelings of respect for Papuans and all things Papuan. This could be unique to Manokwari, an outcome of the majority Biak population who have long prized themselves in defining the terms 
and symbols of Papuan nationalism (Rutherford 2012) or, it could be a resistant product of rapid change in light of feeling threats to the religious character of the Gospel City. I suspect this spirit transcends place as gauged by the ubiquity of the 'I love Papua' t-shirts, the rise and rise of Batik Papua (Cookson 2008), contemporary songs that extol Papua's majestic beauty, and in the words of praise I have heard in sermons in other cities for God blessing Papua with bounty. Bahasa Papua (the Papuan dialect of Indonesian) has become ever more elaborated in mediating a pan-regional identity and friends were eager to explain how Papuans say things, their words, tone and inflection, as opposed to people from Ambon, Makassar and Java. Sentiments that underpinned pride resemble the recently classified emotion of 'elevation' (Haidt 2000), a feeling of moral beauty and uplift closely related to awe and gratitude. Exploring Papuanness in relation to feelings of elevation is particularly promising since, as a moral emotion, evidence points to its power in building cohesion through commitment to a subjectively identified community.

Finally, let me briefly raise the issue of how local embracements and rejections of hip hop might inspire future research into Papuan identity and nationalism. For one, it demands we inquire into how Papuanness is being operationalised as a series of supposed facts about moral attributes and character. What is it to 'be Papuan', who has the authority to claim Papuanness, and how are its emergent qualities becoming moral proscriptions to judge, shape and even enforce behaviour in new social worlds? It would be useful to compare and contrast the moral contours of ethnic identities in daily conversations and practices as well as in the varied discourse of elites. How are pastors invoking Papuan futures to argue for certain moral outcomes? What moral arguments are implicit or explicit in new literatures that speak to the economic and political challenges facing Papua? How are notions of an indigenous essence being manipulated in discourses of moral panics? Exploring the construction of moral character will lead us to consider how Papuanness is much more than a symbol of unification, it is a trope deployed in contests about proper being in the world at a time of growing moral and religious anxiety.

When Papuan pride is conceptualised in terms of a vitalising emotional core generative of novel cultural content, we are encouraged to look beyond the expected for expressions of ethnic identity. As well as the symbolic realms of Christianity and tradition, Papuanness is being communicated, with or without the political aim of merdeka, through emergent and unexpected domains like pop culture and language. If Papuanness can be known consciously through alternative discourse and politics, how is it generationally inflected, or, for that matter, does it have a gender, a class, or another social axis? As Papuan societies become fractured along new lines of economy and power and as the region 
moves into an era of complex and digitised global processes, it is timely that we strive to access marginal, incipient and heterogeneous manifestations of Papuan pride and nationalism.

\section{References}

Acciaioli, Greg 1985. 'Culture as Art: From Practice to Spectacle in Indonesia'. Canberra Anthropology 8(1-2): 148-174.

Appadurai, Arjun 1990. 'Disjuncture and Difference in the Global Cultural Economy'. Public Culture 2(2): 1-24.

Ballard, Chris 2002. 'West Papua'. Contemporary Pacific 14: 467-476.

Braithwaite, John, Braithwaite, Valerie, Cookson, Mike and Dunn, Leah 2010. Anomie and Violence: Non-truth and Reconciliation in Indonesian Peacebuilding. Canberra: ANU E Press.

Brison, Karen 2008. Our Wealth is Loving Each Other. Plymouth: Lexington Books.

Bucholtz, Mary 2002. 'Youth and Cultural Practice'. Annual Review of Anthropology 31: 525-152.

Chang, Jeff 2006. Can't Stop Won't Stop: A History of the Hip-Hop Generation. New York: St Martin's Press.

Chauvel, Richard 2005. Constructing Papuan Nationalism: History, Ethnicity, and Adaptation. Policy Studies 14. Washington D.C.: East-West Center Washington.

Cohen, Stanley 1980. Folk Devils and Moral Panics: The Creation of the Mods and Rockers. Oxford: Martin Robertson.

Cookson, Mike 2008. Batik Irian: Imprints of Indonesian Papua. PhD thesis, The Australian National University.

Cordell, Marni 2013. 'Indonesian Police Open Fire on Civilians in West Papua'. The Guardian, 25 September 2013. Accessed on 10 February 2014.

Davidson, Jamie and Henley, David (eds) 2007. The Revival of Tradition in Indonesian Politics: The Deployment of Adat from Colonialism to Indigenism. Oxon, New York: Routledge.

Ellis, Trey 1989. 'The New Black Aesthetic'. Callaloo 38: 233-243. 
From 'Stone-Age' to 'Real-Time'

Fanon, Franz 1986. Black Skin, White Masks. London: Pluto Press.

Farhadian, Charles 2005. Christianity, Islam and Nationalism in Indonesia. New York and London: Routledge.

Flassy, Don A.L. 1999. Basic Guidelines, State of West Papua: Papua-Melanesia Threefold Logic, Basic Ideology, General Governance, Constitution of West Papua. Port Numbay (Jayapura): Fajar Melanesia.

Gagné, Natacha and Salaun, Marie 2012. 'Appeals to Indigeneity: Insights from Oceania'. Social Identities 18(4): 381-398.

Giay, Benny 2000. Menuju Papua Baru: Beberapa Pokok Pikiran sekitar Emansipasi Orang Papua. Jayapura: Deiyai and Elsham Papua.

Giay, Benny and Ballard, Chris 2003. 'Becoming Papuans: Notes Towards a History of Racism in Tanah Papua.' Paper presented at the annual meeting of the American Anthropological Association, Chicago.

Glazebrook, Diana 2004. 'Teaching Performance Art is Like Sharpening the Blade of a Knife'. The Asia Pacific Journal of Anthropology 5(1): 1-14.

Haidt, Jonathon 2000. 'The Positive Emotion of Elevation'. Prevention \& Treatment 3(1): 1-5.

Hellman, Jorgen 2003. Performing the Nation: Cultural Politics in New Order Indonesia. Nordic Institute of Asian Studies. Copenhagen: NIAS Press.

Herdt, Gilbert (ed.) 2009. Moral Panics, Sex Panics: Fear and the Fight over Sexual Rights. New York: New York University Press.

Herdt, Gilbert and Leavitt, Stephen (eds) 1998. Adolescence in Pacific Island Societies. Pittsburgh: University of Pittsburgh Press.

International Crisis Group (ICG) 2001. 'Indonesia: Ending Repression in Irian Jaya'. ICG Asia Report No 23. Jakarta/Brussels.

Kirksey, Eben 2102. Freedom in Entangled Worlds: West Papua and the Architecture of Global Power. Durham: Duke University Press.

Knauft, Bruce 2002. Critically Modern: Alternatives, Alterities, Anthropologies. Bloomington: Indiana University Press.

Lock, Margaret 2001. 'The Tempering of Medical Anthropology: Troubling Natural Categories'. Medical Anthropology Quarterly 15: 478-492. 
Munoz-Laboy, Miguel, Weinstein, H. and Parker, Richard 2007. 'The Hip-Hop Club Scene: Gender, Grinding and Sex'. Culture, Health \& Sexuality 9(6): 615-628.

Munro, Jenny 2009. Dreams Made Small: Humiliation and Education in a Dani Modernity. PhD thesis, The Australian National University. Available at: www.papuaweb.org.

Munro, Jenny 2013. 'The Violence of Inflated Possibilities: Education, Transformation and Diminishment in Wamena, Papua'. Indonesia 95: 25-46.

Ottow, Carl Wilhelm and Geissler, Johann Gottlob 1857. Geelvink Bay:A Brief Survey of the Land and People on the Northeast Coast of New Guinea (Mansinam, 29 January 1857). Introduced and Translated by Jan A. Godschalk. Nationaal Archief, Den Haag, Ministerie van Kolonie n, 18501900, access number 2.10.02, inventory number 889 .

Perwita, A.A.B. 2007. Indonesia and the Muslim World: Islam and Secularism in the Foreign Policy of Soeharto and Beyond. Nordic Institute of Asian Studies. NIAS Reports No. 50. Copenhagen: NIAS Press.

Poli, W.I.M., Salle, Agustinus, Purnomo, Bazergan, Etty, Manda, Martin L., Abubakar, M.D. 2008. Habel Melkias Suwai: The Empowering Inner Voice: The Concept of Community Empowerment in the Regency of Jayapura (English Abridged Version). Makassar: Hasanuddin University Identitas.

Prasetyaningsih, Luh Ayu S. 2007. The Maze of Gaze: The Color of Beauty in Transnational Indonesia. PhD thesis, University of Maryland.

Purdey, Jemma 2004. 'Unity in Diversity: Ethnicity and the Nation.' Inside Indonesia 78: Apr-Jun.

Rizzo, Susanna 2004. From Paradise Lost to Promised Land: Christianity and the Rise of West Papuan Nationalism. PhD thesis, University of Wollongong.

Robbins, Joel 2004. Becoming Sinners: Christianity and Moral Torment in a Papua New Guinea Society. Berkeley: University of California Press.

Robbins, Joel 2005. 'Humiliation and Transformation: Marshall Sahlins and the Study of Cultural Change in Melanesia'. In Robbins, Joel and Wardlow, Holly (eds), The Making of Global and Local Modernities in Melanesia: Humiliation, Transformation, and the Nature of Cultural Change. Aldershot, Burlington: Ashgate, 3-21.

Roth-Gordon, Jennifer 2013. 'Racial Malleability and the Sensory Regime of Politically Conscious Brazilian Hip Hop'. The Journal of Latin American and Caribbean Anthropology 18(2): 294-313. 
From 'Stone-Age' to 'Real-Time'

Rutherford, Danilyn 2003. Raiding the Land of the Foreigners: The Limits of the Nation on an Indonesian Frontier. New Jersey: Princeton University Press.

Rutherford, Danilyn 2012. Laughing at Leviathan: Sovereignty and Audience in West Papua. Chicago: University of Chicago Press.

Sahlins, Marshall 1992. 'The Economics of Develop-Man in the Pacific'. Res 21, $12-25$.

Schaefer, S. 2013. 'What Gives Rise to Moral Outrage?' Inside Indonesia 111: Jan-March.

Smythe, Julian 2013. 'The Living Symbol of Song in West Papua: A Soul Force to be Reckoned With'. Indonesia 13(95): 73-91.

Stemmler, Susanne 2013. 'The Global Cipha: The Transcultural Dynamics of a Black Aesthetics in James G. Spady's Rap Oeuvre'. Western Journal of Black Studies 37(2): 112-125.

Swarati, Stefani Haning 2012. 'Selling Nationalism'. Inside Indonesia 110: OctDec.

Upton, Stuart 2009. The Impact of Migration on the People of Papua, Indonesia: A Historical Demographic Analysis. PhD thesis, University of New South Wales.

Wallace, Anthony 1956. 'Revitalization Movements'. American Anthropologist 58(2): 264-281.

Wardlow, Holly 2006. Wayward Women: Sexuality and Agency in a New Guinea Society. Berkeley, Los Angeles and London: The University of California Press.

Watts, E. 1997. 'An Exploration of Spectacular Consumption: Gangsta Rap as Cultural Commodity'. Communication Studies 48(1): 42-58.

Weeks, Jeffery 2012. Sex, Politics and Society: The Regulation of Sexuality Since 1800. London: Pearson Education. 
This text is taken from From 'Stone-Age' to 'Real-Time': Exploring Papuan Temporalities, Mobilities and Religiosities, edited by Martin Slama and Jenny Munro, published 2015 by ANU Press, The Australian National University, Canberra, Australia. 